\title{
Identity Construction in I Know Why the Caged Bird Sings*
}

\author{
Dongxu Zhao \\ Jilin Institute of Chemical Technology \\ Jilin, China 132022
}

\begin{abstract}
Maya Angelou is a noted African American writer of seven autobiographies, which assured her a prominent place in American literature and she was heralded as a new kind of memoirist, one of the first African American women who was able to publicly discuss her personal life. Among those autobiographies which focus on her childhood and early adulthood experiences, I Know Why the Caged Bird Sings (1969) is the first and best known. This paper aims to analyze Maya's initiation through identity construction, to be specific, from losing her identity because of her abandoned experience and her ugly appearance to confirming her identity by the influence of grandmother Henderson and the boxing Championship of her people. It is hoped to provide a new perspective to appreciate the work and give some reference to the people who are on the way of identity construction.
\end{abstract}

Keywords-Maya Angelou; "I Know Why the Caged Bird Sings"; identity construction

\section{INTRODUCTION}

I Know Why the Caged Bird Sings was written by Maya Angelou who is an American autobiographer, poet, journalist, educator and film director. She is a remarkable Renaissance woman who is hailed as one of the great voices of contemporary literature. She is best known for her series of six autobiographies, which focus on her childhood and early adulthood experiences. American Scholar Joanne M. Braxton said she is "America's most visible black female autobiographer". In 1993, Maya Angelou recited her poem "On the Pulse of Morning" at President Bill Clinton's inauguration, the first poet to make an inaugural recitation since Robert Frost at John F. Kennedy's inauguration in 1961.

If growing up is painful for the Southern Black girl, being aware of her displacement is the rust on the razor that threatens the throat.

\section{It is an unnecessary insult. (6)}

At the beginning of the novel, three-year-old Maya was sent from California to Arkansas along with her four years old brother, Bailey. In the following years, she keeps on moving from Stamps to St. Louis, then back to Stamps, and finally to California. The young Maya's physical mobility

*Project: This paper is the stage research result of the "13th Five-year" Social Science Project in 2017 (JJKH20170230SK) of Education Department of Jilin Province. serves as a metaphor for a psychic mobility, since she must find her way out of the psychological and spiritual immobility and confirm her identity.

\section{THE LOST OF IDENTITY}

\section{A. Parents' Abandonment}

Maya and her brother Bailey were sent to grandmother after the ending of their parents' marriage. At that time Maya was three, and Bailey was four. They were treated as luggage with tags which wrote "To Whom It May Concern". Although "I [Maya] don't remember much of the trip" (6), nevertheless, the abandoned experience must give her a heavy blow. So she and Bailey kept on asking themselves, "Why did they send us away? And what did we do so wrong? So Wrong? Why, at three and four, did we have tags put on our arms to be sent by train alone from Long Beach, California, to Stamps, Arkansas"(51)?

In Maya's mind, they must do something wrong, something that can't be forgiven by parents, so their parents abandoned them. But she can't find out what she did so wrong, and in what way she can amend "her fault", which make Maya deny herself constantly. Maya bears spiritual torture, and frequently wonders what she should do. Ann Smith points out "such rejection a child internalizes and translates as a rejection of self: ultimately the loss of home occasions the loss of self-worth" (Sidonie Ann Smith, 1990: $6)$. Therefore, Maya, at this stage, lost self-worth and was on the edge of losing her identity.

When she and her brother arrived at Stamps, a segregated southern town, "it regarded us [them] a while without curiosity but with caution, and after we [they] were seen to be harmless (and children) it closed in around us [them], as a real mother embraces a stranger's child. Warmly, but not too familiarly" (7). As Stamps spent time to accept new arrivals, it also cost Maya a long time to adjust to the strange place. Although it seemed that she later adapted to the life in the Southern town and forgot her tragic abandonment, she still felt lonely as an unwanted child. When she missed her mother, Maya used her imagination to comfort herself. She supposed her mother was dead, lying in the coffin, and being covered with a sheet. Since she couldn't fill in the features of her mother's face, she printed M O T H E R across the big. Then she would cry for her "dead" mother. 
However, imagination doesn't equal to facts. At the age of six, sensitive Maya received her mother's Christmas gifts. The awful Christmas gifts smash Maya's imagination into pieces, because it proved her mother was alive. The reality is that she is the abandoned, unwanted, troublemaker child. That devastated to her sense of self once again. She lost her identity at last.

\section{B. Wish for Becoming White}

Maya, an intensely self-conscious child, feels that she is ugly, inferior and her true self is obscured. In the Easter morning church service, she recited a poem in mind: "What you looking at me for? I didn't come to stay..." (1). Lack of confidence and self-loathing make Maya think that everyone in church is staring at her because of her skinny legs and dirty skin color. As an unwanted child, Maya feels she is unwelcomed and nasty. She even wants to be somebody else. Sometimes, she is conscious of her dual self, which is the constant subject of her fantasies.

One day I woke out of my black ugly dream, and my real hair, which was long and blond, would take the place of the kinky mass that Momma wouldn't let me straighten? My light-blue eyes were going to hypnotize them, after all the things they said about "my daddy must have been a chinaman"..'Because I was really white and because a cruel fairy stepmother, who was understandably jealous of my beauty, had turned me into a too-big Negro girl, with nappy black hair, broad feet and a space between their teeth that would hold a number-two pencil. (4-5)

Maya suffered from a strong case of racial self-hatred, fantasizing that she was "really white," with "light-blue eyes" and "long and blond" hair. She even created a "cruel fairy stepmother", who turned her into a too-big Negro girl because of jealousy. According to American scholar Pierre A. Walker, "Maya entirely separates her sense of self from her sense of race, and this is an important part of her identity crisis, since she refuses to accept being who she is and hankers after a foreign identity that is a compound of received ideas of white feminine beauty" (Pierre A. Walker, 1995: 97).

Moreover, the Christmas gifts from her mother not only confirmed that Maya's mother was still alive but also caused her to have a sense of self-loathing. Maya received a doll with blue eyes, rosy checks, and yellow hair - symbols of white beauty, which was "right with the world". However, the doll was totally different from her black eyes, black skin and black hair, and made her think she was ugly and loath her appearance. The pervasive racial prejudice at that time influenced Maya imperceptibly, which shook her selfjudgment, even resulted in her losing identity. In this stage, she doesn't know who she was and what she would do, and what role should she play in the society. Maya totally lost her identity.

\section{THE RECOGNITION OF IDENTITY}

Abandoned by her parents and disgusting at her race and appearance, Maya experienced an identity crisis. As in many African American novels, the community is the root of the identity of the protagonist, so when Maya was in the maze of identity, it was the black community that gave her a hand, helped her establish confidence and recognize her uniqueness.

\section{A. Momma's Influence}

Maya came to Stamps when she was three, and brought up by her grandmother Henderson, or Momma, as Maya calls her. In little Maya's eyes, Momma was very sturdy and powerful.

I saw only her power and strength. She was taller than any woman in my personal world, and her hands were so large they could span my head from ear to ear. Her voice was soft only because she chose to keep it so. In church, when she was called upon to sing, she seemed to pull out plugs from behind her jaws and the huge, almost rough sound would pour over the listeners and throb in the air. (45)

Momma seems to be a typical image of black women, who is big and strong with large hands and loud voice. Being cared for and protected by such a Momma, Maya had a sense of security.

Apart from physical strength, Momma was very wise and shrewd. She was economically independent by running a general store in Stamps, Arkansas. At the beginning of the 19th century, Momma sold lunches to the sawmen in the east of Stamps and the seedmen in the west. "Her miraculous ability to be in the two places at the same time, assured her business success" (7). Then, she built a stand between the two points and supplied the workers' needs. Some years later, she had the Wm. Johnson General Merchandise Store set up in the heart of the Negro area. The Store sold various goods, including food, clothes, and tools. Besides, anything not visible in the Store could be ordered. "Over the years it has become the lay center of activities in town" (7). During the Depression, all customers had no money, so Momma made a decision to make her store serve as an exchanging center. And she priced each item exchanged on the post:

\section{"15 LB. CAN OF POWDERED MILK IS WORTH 50c IN TRADE}

\section{LB. CAN OF POWDERED EGGS IS WORHT $\$ 1.00$} IN TRADE

\section{0 \#2 CANS OF MACKEREL IS WORTH \$1.00 IN} TRADE. "(49)

In this way, the Store went through the hardest time, and it not only guaranteed that Maya and Bailey had sufficient food and clothes, but also provided an effective exchanging center for those villagers without cash.

In little Maya's eyes, Momma was a super woman, not only because her sturdy body but also because her higher position in the community. Momma ran the only Store in Stamps, and she was a pillar of her church. Besides, Momma was the only black person in the community to be called "Mrs.", which originated from a "Stamps" little legend before Maya and Bailey's arrival. A black man was questioned in Court for assaulting white woman hood. He acknowledged that he took refuge in Mrs. Henderson's Store. 
Then the white judge asked that Mrs. Henderson be subpoenaed. When Momma arrived, the judge was shocked, because he never thought a woman who owned a store in that village turned out to be colored. Much ridiculously, people in her town called a Negro woman Mrs.

Momma not only could run a profitable store, but also could manage a clean and tidy house. Her big, wide white apron "was so stiff by virtue of the starch that it could have stood alone" (28). At the same time, she required Maya and Bailey to be clean. No matter how cold the weather was, Momma would force them to wash faces, arms, necks, legs and feet before going to bed. Momma always told them, "Thou children shall not be dirty and thou shall not be impudent" (26). She also edified them, "Not only was cleanliness next to Godliness, dirtiness was the inventor of misery" (26-27). At first, Maya couldn't understand why Momma was as strict and cruel as to force them to wash by the well even in the bitterest winter. Later, she understood that only by improving their self-value can they establish their racial pride and their identity. And the reason why Momma asked them to keep clean was that she wanted them to value themselves.

Owning land and house, and by running the only Store in Stamps, Momma has more money than all the powhitetrash. But she lives a very thrifty and simple life. "She made my[Maya's] school dresses, underslips, bloomers, handkerchiefs, Bailey's shirts, shorts, her aprons, house dresses and waists from the rolls shipped to Stamps by Sears and Roebuck"(48). And Momma usually cautions Maya and Bailey "waste not, want not". Economical Momma, however, is quite generous to others. She even leads money to the white dentist without any interest. Maya feels that the Negro neighbors are all openhanded and unselfish. "Whatever was given by black people to other Blacks was most probably needed as desperately by the donor as by the receiver" (48). Prudent and generous Momma and the "rich exchange". (48) among black community make Maya realize her people's beauty and virtues. Having been influenced and cultivated by her Momma and the community, she gradually becomes one of them.

According to American professor Mildred A. Hill-Lubin, the grandmother, both in Africa and in America, "has been a significant force in the stability and the continuity of the Black family and the community". (Mildred A. Hill-Lubin, 1986: 257). Annie Henderson is the typical example of the strong grandmother in African-American literature — "the traditional preserver of the family, the source of folk wisdom, and the instiller of values within the Black community" (Mary Jane Lupton, 1990: 260).

Momma used her wisdom to make her family survive through difficulties. Self-sufficient Momma was the center of the family and she set a good example to Maya, and kept proving that every person will succeed if he/she sets his/her minds on it and keeps working on it, no matter he/she is white or colored.

\section{B. Joe Louis's Championship Fight}

Momma set a good example for Maya to know the importance of self-independence and self-respect. She is also Maya's link with the Black folk tradition, as George Kent, Elizabeth Schultz, and other critics have mentioned. Besides, the whole community's solidarity and Joe Louis's victory in the fight also help Maya recognize her racial identity.

After a day's hard work, men, women and their children gathered together at the Store to listen to the radio broadcast of a Joe Louis fight. Uncle Willie turned the radio up so that people on the porch could hear. With the approaching of the fight, the atmosphere became tense, and just at this moment, Maya heard a person say, "I ain't worried 'bout this fight. Joe's gonna whip that cracker like its open season (129)". That humorous prediction, on the one hand, helped to release the intensified mood of people around, and on the other, showed their racial confidence, which helped to stimulate the formation of Maya's racial pride.

At the climax of the fight, the reporter said that the contender kept raining the blows on Louis and he was going down. At this moment, all the people felt strained. "The men in the Store stood away from the walls and at attention. Women greedily clutched the babes on their laps while on the porch the shuffling and smiles, flirting and pinching of a few minutes before were gone" (131). Maya, together with her people, had a shared experience and the same sympathy of feeling. Joe Louis became symbolic of their repressed selves or even the whole black people. So Maya thought Joe's lose meant "the end of the world" (131), because that might prove "we [they] were lower types of human being. Only a little higher than the apes" (131). All people in the Store worried about the fight, and they didn't breathe, didn't hope, and only waited quietly. At the very moment, Joe stood up from the ropes and moved towards the center. He seemed mad and beat the contender fiercely to the ground.

As Joe Louis won the boxing match, all the black audience was relieved. American critic Myra K. McMurry commented that "his [Louis'] victory limited and defined by the boxing ring, is nonetheless a spiritual victory for all Blacks" (Myra K. McMurry, 110). In Maya's mind, Joe Louis's victory proved that they were the strongest people in the world; they were not inferior to any other people at least in this field. Maya began to realize the strength of her race and the power of her united community, which helped Maya appreciate blacks' strength and recognize her real identity.

\section{THE CONFIRMATION OF IDENTITY}

Along with the influence of her people and community, Maya got back her confidence little by little. Dignified Momma and strong Joe Louis showed to Maya that being a black could also succeed and have his/her social status, which gave Maya great courage to confirm her identity and experience something totally new to her.

\section{A. The Driving of a Car All by Herself}

Maya's father, Bailey Sr., was a less prominent character in the book. He represented the absent father, the man who 
was not there for his children, literally and figuratively. Such a kind of figure was prevalent in American literature, among urban and rural, poor and middle-class, black and white families. Maya saw her father only twice in Caged Bird the first time was when her father drove his children to St. Louis, and the second time when Maya visited him for a bizarre summer vacation in the southern California.

One evening during her visit, Daddy announced that he would take Maya, not his girlfriend Dolores, to Mexico to buy food for the weekend the next day. That news made Maya excited and Dolores jealous on the contrary, which led to a display of violence later in the novel.

After arriving at the Mexican bar, Daddy drank a lot, then left Maya in that raunchy bar and went off with his Mexican woman. When Maya couldn't find her Daddy, she felt panic and nervous, so she locked herself in the car. After a long fearful waiting, Daddy showed up finally, but being propelled by the small woman. He was intoxicated and when they got him into the car, he began snoring, and then fell into a deep and long sleep. How could they get home? Daddy was drunk. Maya had never driven a car before. At this time, Maya told herself, "I was superbly intelligent and had good physical coordination. Of course I could drive. Idiots and lunatics drove cars, why not the brilliant Marguerite Johnson?"(230).

With the help of Mexicans and based on the careful observation of others driving before, Maya got on the car and tried to drive. After a tremendous work, she started the car and drove on a deserted, dark country road for miles. Gradually, Maya felt "strange enough, fear was absent from my [her] sensations" (233).

Although Daddy was still irresponsible, in the same way as he abandoned her years ago, Maya chose to solve the problem positively this time. She drove all by herself in an abandoned place fearlessly and successfully until she reached the border line of Mexico and America. Different from denying herself, this time, she thought "I was superbly intelligent and had good physical coordination. Of course I could drive. Idiots and lunatics drove cars, why not the brilliant Marguerite Johnson" (230)? Maya acknowledged her intelligence, her ability and her identity, and grew to be a self-assured girl.

\section{B. Escape from Home}

Like most American initiation story, Caged Bird also has the plot of leaving home, which is to be seen as one of the most important features of initiation story, in which the protagonist will usually go through some trial and tribulation, and then be awakened to the reality. Finally, he/she grows up. Professor Rui Yuping wrote that "Leaving home is one of the most important structural elements of an initiation story. Leaving home means taking actions. The process of doing is often reflected in the journey after leaving home. Results come from doings. Only the protagonist leaving home could he/she have findings. Leaving home also symbolizes leaving the original place and move to a new one" (Rui Yuping, 2004: 85).
After Maya and Daddy drove back home, Dolores was very angry with them. She quarreled with Daddy and then Daddy left home furiously. Maya intended to comfort Dolores, which unfortunately caused violence between them. Maya was cut by Dolores. Daddy had to send Maya to his friend's home to regain her health. But Maya thought "if I disappeared Dad would be relieved, not to mention Dolores" (243). Therefore, she decided to leave.

She was away from home for one month, during which she slept in a deserted car in a junkyard, where she met other waifs. Among them were Negros, Mexicans and whites. They were from different parts of the country, but they got along with each other very well. They accepted and welcomed Maya as long as she followed their common rule that no two people of opposite sex slept together. After a few days, Maya found that, "everyone worked at something. Most of the girls collected bottles and worked weekends in greasy spoons. The boys mowed lawns, swept out pool halls and ran errands for small Negro-owned stores. All money was held by Bootsie and used communally" (246). At weekends, they had parties together. Maya worked and played with this group of children coming from different races. She found that there was no difference between whites and blacks, and they are actually "the brotherhood of man" (247). The junkyard life gave Maya freedom and relaxation, but she wouldn't like to live in "the unrestrained life" (248) during her left time. A month later, Maya called Mother and decided to go back home. She told her new friends, and received everyone's wishes. In her cooperation with the whites and other races in the small community, she came to realize that all the races were equal and necessary parts of the world. She said that she "was never again to sense myself [herself] so solidly outside the pale of the human race. The lack of criticism evidenced by our ad hoc community influenced me, and set a tone of tolerance for my [her] life" (247).

Maya entered another world by escaping from home, which was totally different from hers. This new world exposed to her with new rules, new relations and new values, which opened her mind and shook her former attitude. She felt equal and friendly among different races personally and the acceptance and welcome by others helped Maya establish confidence of her race and reconfirm her identity.

\section{CONCLUSION}

Losing, searching and confronting one's identity are the inevitable and painful experiences for most adolescence. But for Maya, a Southern Negro girl, it is much more difficult as there are more social forces that limit her. Hence, her success of questing for self encourages numerous Black women to find themselves, establish confidence, and live bravely with optimistic attitude.

\section{REFERENCES}

[1] Angelou, Maya. I Know Why the Caged Bird Sings. London: Virago Press, 1984. 
[2] Chang, Yaoxin. A Survey of American Literature. Tianjin: Nankai University Press, 2004.

[3] Hill-Lubin, Mildred A. "The Grandmother in African and AfricanAmerican Literature: A Survivor of the Extended Family." Ngambika: Studies of Women in African Literature. Ed. Carole B. Davies and Anne A. Graves. Trenton: Africa World, 1986. 257-70.

[4] Lupton, Mary Jane. "Singing the Black Mother: Maya Angelou and Autobiographical Continuity." Black American Literature Forum 24 (1990) : 257-276.

[5] Mcmurry, Myra K. "Role-Playing as Art in Maya Angelou's 'Caged Bird"” South Atlantic Bulletin 41 (1976): 106-111.

[6] Walker, Pierre A. "Racial Protest, Identity, Words, and Form in Maya Angelou's I Know Why the Caged Bird Sings." College Literature 22 (1995) : 91-108.

[7] Rui Yuping. A Study of American Initiation Stories[M]. Beijng: China Social Sciences Publishing House, 2004. 